\title{
The 55-kD Tumor Necrosis Factor Receptor on Human Keratinocytes Is Regulated by Tumor Necrosis Factor-Alpha and by Ultraviolet B Radiation
}

\author{
Uwe Trefzer, Manfred Brockhaus, ${ }^{*}$ Hansruedi Lötscher, ${ }^{*}$ Frauke Parlow, Anne Budnik, Markus Grewe, ${ }^{\ddagger}$ Helmut Christoph, \\ Alexander Kapp, Erwin Schöpf, Thomas A. Luger, ${ }^{5}$ and Jean Krutmann \\ Departments of Dermatology and ${ }^{\ddagger}$ Biochemistry, University of Freiburg, Germany; ${ }^{\S}$ LBI, DVS, Cellbiology, Department of Dermatology, \\ University of Münster, Germany; *PRTB, F. Hoffmann-LaRoche, Ltd., Basel, Switzerland
}

\begin{abstract}
In previous studies we showed that cultured human keratinocytes expressed the 55-kD TNF receptor (TNFR) and that its expression was important for TNF $\alpha$-mediated upregulation of intercellular adhesion molecule-1 (ICAM-1) expression on keratinocytes. Because factors that either reduce or enhance TNFR expression are likely to have a major impact on the biological effects of TNF $\alpha$ on keratinocytes, these studies were conducted to determine the factors that regulate its expression on keratinocytes. Using reverse transcriptase polymerase chain reaction, human keratinocytes were shown to lack $75-k D$ TNFR expression, indicating that TNF responsiveness of human keratinocytes critically depended on regulation of 55-kD TNFR expression. Human keratinocyte 55-kD TNFR surface and mRNA expression was found to be regulated in vitro by recombinant human (rh) TNF $\alpha$. Stimulation of keratinocytes with $\operatorname{rhTNF} \alpha$ initially decreased, but later increased, 55-kD TNFR surface expression. This biphasic modulation of 55-kD TNFR surface expression was associated with concomitant changes in 55-kD TNFR mRNA expression. Ultraviolet B (UVB) radiation, a well-known inducer of synthesis and secretion of TNF $\alpha$ by human keratinocytes, was found to mimic TNF $\alpha$-induced modulation of 55-kD TNFR surface and mRNA expression via a TNF $\alpha$-mediated autocrine regulatory mechanism. Production of soluble 55-kD TNFR by human keratinocytes remained unaffected by TNF $\alpha$ stimulation or UVB irradiation. These studies provide clear evidence that membrane expression of the human 55-kD TNFR may be regulated in human keratinocytes by the ligand itself: TNF $\alpha$. Since in previous studies UVB irradiation transiently inhibited TNF $\alpha$ induced human keratinocyte ICAM-1 expression, it is proposed that UVB radiation-induced biphasic modulation of human keratinocyte 55-kD TNFR expression may affect the capacity of these cells to respond to TNF $\alpha$. (J. Clin. Invest. 1993. 92:462-470.) Key words: photoimmunology $\bullet U V B$ radiation - ICAM-1 - TNF receptor - keratinocytes
\end{abstract}

This work was presented in part at the Annual Meeting of the Society for Investigative Dermatology, Baltimore, MD, 29 April-2 May 1992.

Address reprint requests to Jean Krutmann, Department of Dermatology, University of Freiburg, Hauptstr. 7, W-7800 Freiburg i. Br., Germany.

Received for publication 7 August 1992 and in revised form 3 February 1993.

J. Clin. Invest.

(c) The American Society for Clinical Investigation, Inc.

0021-9738/93/07/0462/09 \$2.00

Volume 92, July 1993, 462-470

\section{Introduction}

Two different types of TNF receptors (TNFR) ${ }^{1}$ have been identified in human cells: the 55-kD TNFR (type 1 TNFR, type B TNFR, TNFR-II) and the 75-kD TNFR (type 2 TNFR, type A TNFR, TNFR-I) (1-7). These two receptor molecules, which bind both TNF $\alpha$ and TNF $\beta$ with high affinity, differ markedly in their intracellular domains and mediate distinct cellular responses. For example, antibodies directed against the human 75-kD TNFR, but not the human 55-kD TNFR, block TNF $\alpha$-induced proliferation of activated human B lymphocytes (8). In murine systems, on the other hand, the $55-\mathrm{kD}$ TNFR initiates signals relevant for the cytotoxic action of TNF $\alpha$, whereas the 75-kD TNFR mediates TNF-induced proliferation of thymocytes and cytotoxic $T$ cells (9). The two types of TNFR are differentially expressed in tissues and their expression is regulated independently (8-11). For example, resting $\mathrm{T}$ - and $\mathrm{B}$ cells express low levels of both receptors. Upon activation, expression of the $75-\mathrm{kD}$, but not the 55-kD, TNFR is markedly enhanced (11). In contrast, little is known about the mechanisms by which expression of the human $55-\mathrm{kD}$ TNFR may be regulated.

In previous studies we have shown that human epidermal keratinocytes express 55-kD TNFR and that these receptor molecules mediate TNF-induced keratinocyte surface expression of the adhesion molecule intercellular adhesion molecule1 (ICAM-1) (12). Keratinocyte ICAM-1 expression constitutes an important prerequisite for their capacity to physically interact with leukocytes. Thus, regulation of 55-kD TNFR expression may play an important role in initiating changes in keratinocytes that allow their participation in cutaneous inflammatory reactions $(13,14)$. In the present study, we demonstrated that TNF $\alpha$ regulated TNFR on keratinocytes in a biphasic manner, first downregulating, and then upregulating their expression. Ultraviolet $B(U V B)$ radiation was also found to regulate TNFR expression by stimulating TNF $\alpha$ release, which then acted in an autocrine manner to produce a similar biphasic response.

\section{Methods}

Cytokines, antibodies, and reagents. Recombinant human (rh) TNF $\alpha$ was kindly provided by Boehringer Mannheim GmBH (Mannheim, Germany). [ $\left.{ }^{125} \mathrm{I}\right] \mathrm{TNF} \alpha$ with a specific activity of $65.5 \mu \mathrm{Ci} / \mu \mathrm{g}$ was purchased from DuPont De Nemours (Dreieich, Germany). The polyclonal rabbit anti-human TNF $\alpha$ antibody IP-300 (IgG and IgM) was obtained from Genzyme Corp. (Boston, MA) and was supplemented

1. Abbreviations used in this paper: ICAM-1, intercellular adhesion molecule-1; KGM, keratinocyte growth medium; rh, recombinant human; s, soluble; TNFR, TNF receptors. 
with $0.1 \% \mathrm{BSA}$ as a carrier protein to prevent absorption of the antibodies to plastic. The IP-300 antibody was used at a 1:50 dilution, which corresponds to a neutralizing activity of 20,000 U TNF $\alpha$ bioactivity, as measured by the L929 cell cytotoxicity assay. As a control, a rabbit preimmune serum was used (Hoffmann LaRoche Ltd., Basel, Switzerland). mAb htr-9 (mIgGl), which specifically recognizes the ligandbinding site of the 55-kD TNFR, and mAb utr-1 (mIgGl), which is directed against the human 75-kD TNFR, were used at a concentration of $100 \mu \mathrm{g} / \mathrm{ml}(7,12)$. Mouse IgG1 isotype control antibodies were obtained from Sigma Chemicals Co. (St. Louis, MO). The FITC-conjugated affinity-purified goat anti-mouse $(\mathrm{Fab})_{2}^{\prime}$ was purchased from Dianova, (Hamburg, Germany). Cycloheximide was obtained from Sigma Chemical Co. (Munich, Germany).

Cell culture. Long-term cultures of normal human keratinocytes were prepared from neonatal foreskin as described previously and maintained in a defined keratinocyte growth medium (KGM; Clonetics Corp., San Diego, CA) $(12,15,16)$. Hydrocortisone was omitted from the culture medium $48 \mathrm{~h}$ before testing. For all experiments, fourth and fifth passage cells at subconfluency were used. Cells were cultured at $37^{\circ} \mathrm{C}$ in a humidified atmosphere containing $5 \% \mathrm{CO}_{2}$. In addition, in some experiments RNA was extracted from cells of the human epidermoid carcinoma cell line KB (American Type Culture Collection, Rockville, MD), which were maintained in Eagles modified essential medium (Gibco Laboratories, Berlin, Germany) containing 10\% FCS (Gibco Laboratories) as previously described $(12,14$, 15). The monocytoid cell line HL60 cells (American Type Culture Collection, Rockville, MD) was maintained in RPMI 1640 medium (Gibco) supplemented with 10\% FCS (Gibco Laboratories).

$U V$ radiation. For UVB irradiation, medium was replaced by PBS and cells were exposed to UV radiation $\left(0-100 \mathrm{~J} / \mathrm{m}^{2} \mathrm{UVB}\right)$ using a bank of four FS20 sunlamp bulbs (Westinghouse Electric Corp., Pittsburgh, PA), which are known to emit primarily in the UVB range $(280-320 \mathrm{~nm})(15,16)$. The UVB output was monitored by means of an IL 1700 research radiometer and SEE 240 UVB photodetector (International Light Inc., Newburyport, MA) and was $\sim 24 \times 10^{-5} \mathrm{~W} /$ $\mathrm{cm}^{2}$ at a tube to target distance of $22 \mathrm{~cm}$.

Immunofluorescence flow cytometry. Keratinocytes were collected by a 45 -min treatment with prewarmed PBS containing $10 \mathrm{mM}$ EDTA. Washed cells $\left(5 \times 10^{5}\right)$ were incubated with the mAb htr-9 $(100 \mu \mathrm{g} / \mathrm{ml})$ or the equivalent amount of a mouse IgGl isotype control antibody for $30 \mathrm{~min}$ at $4^{\circ} \mathrm{C}(12)$. Subsequently, cells were washed three times in PBS containing $0.05 \%$ sodium azide, resuspended, and incubated with a 1:20 dilution of goat anti-mouse FITC-( Fab' $\left.^{\prime}\right)_{2}$ for $30 \mathrm{~min}$ at $4^{\circ} \mathrm{C}$. Cells were then washed three times and were analyzed immediately using a flow cytometer (FACScan ${ }^{\oplus}$; Becton-Dickinson \& Co., Mountain View, CA ). Before analysis, cells were routinely stained with propidium iodine to exclude dead cells and in most instances 5,000 cells were assessed in each sample. Data are given as histograms of fluorescence intensity versus cell number.

Binding of $\left[{ }^{125} I\right] T N F \alpha$ to keratinocytes. Binding of TNF $\alpha$ to keratinocytes was determined as previously described (17). Binding assays were performed as duplicates in six-well plates. Briefly, $\left[{ }^{125} \mathrm{I}\right] \mathrm{TNF} \alpha$ $(0.13 \mathrm{nM})$ was added in ice-cold binding buffer to keratinocytes in subconfluent cultures at $4^{\circ} \mathrm{C}$ for $8 \mathrm{~h}$ to achieve maximal binding (17). Cells were washed three times with ice-cold binding buffer, and the cell-bound radioactivity was solubilized in $1 \%$ SDS and quantitated in a gamma scintillation counter. Nonspecific binding was determined in the presence of a 200-fold excess of TNF $\alpha$ and was subtracted from the total binding to determine specific binding. Nonspecific binding was in general $<10 \%$ and did not vary between duplicate dishes by $>10 \%$. Keratinocytes were found to specifically bind [ $\left.{ }^{125} \mathrm{I}\right] \mathrm{TNF} \alpha$ and to express a single class of TNFR with a $K_{\mathrm{d}}$ of $\sim 5 \times 10^{-10} \mathrm{M}$, confirming previous results (17).

Acid stripping. To remove receptor-bound TNF $\alpha$, keratinocytes were treated by acid stripping as previously described (18-20). Briefly, UVB-irradiated keratinocytes were cultured for $6 \mathrm{~h}$, washed, and subsequently treated with $50 \mathrm{mM}$ glycine buffer ( $\mathrm{pH} 3$ ) containing $0.15 \mathrm{M}$ $\mathrm{NaCl}$ for 2 min at $4^{\circ} \mathrm{C}$. The cells were then washed at $4^{\circ} \mathrm{C}$ with PBS and analyzed for the presence of TNFR either by using mAb htr-9 or by using [ $\left.{ }^{125} \mathrm{I}\right] \mathrm{TNF} \alpha$. Acid stripping did not alter the reactivity of mAb htr- 9 or the mIgG1 isotype control antibody with keratinocytes. Control experiments were performed to exclude that acid stripping of keratinocytes would cause metabolic changes that might inhibit their capacity to decrease TNFR expression. Accordingly, the capacity of UVBirradiated, acid-stripped keratinocytes to internalize TNFR was assessed as previously described using ${ }^{125}$ ITNF $\alpha(18-20)$. These experiments indicated that a 2-min acid stripping did not inhibit ligand-induced TNFR internalization (data not shown).

$T N F \alpha E L I S A$. A commercially available ELISA was used for measuring human TNF $\alpha$ (Endogen Inc., Boston, MA) (21). This kit uses a mouse anti-TNF $\alpha$ mAb and a rabbit polyvalent anti-TNF $\alpha$ antibody. It is sensitive to $10 \mathrm{pg} / \mathrm{ml} \mathrm{TNF} \alpha$ and does not cross-react with human TNF $\beta$, IL-1, or IL-6.

Assay for soluble TNFR. Soluble (s) TNFR were detected in supernatants derived from human keratinocytes as previously described (22-24). Briefly, 96-well vinyl plates (Dynatech Laboratories, Inc., Alexandria, VA) were sensitized by 24 -h incubation with affinity-purified anti-murine Ig from rabbit ( $10 \mu \mathrm{g} / \mathrm{ml}$ PBS; $100 \mu \mathrm{l}$ per well), washed once with PBS, and incubated overnight with a noninhibitory $\mathrm{mAb}(10 \mu \mathrm{g} / \mathrm{ml}$ in $50 \mathrm{mM}$ Tris $\cdot \mathrm{HCl}, \mathrm{pH} 7.4 ; 140 \mathrm{mM} \mathrm{NaCl}, 5 \mathrm{mM}$ EDTA, $1 \%$ delipidated milk powder; $50 \mu \mathrm{l}$ per well ) against either the 55-kD TNFR ( $\mathrm{mAb}$ htr-20) or against the 75-kD TNFR (mAb utr-4). The wells were washed with PBS and undiluted samples $(45 \mu \mathrm{l})$ of keratinocyte supernatant were added and incubated for $3 \mathrm{~h}$ at $4^{\circ} \mathrm{C}$. The wells were washed again once (PBS) and TNF-binding sites were detected by incubation with [ $\left.{ }^{125} \mathrm{I}\right] \mathrm{TNF}\left(10^{6} \mathrm{cpm} / \mathrm{ml}, 50 \mu\right.$ l per well $)$ for 2 $\mathrm{h}$ at $4^{\circ} \mathrm{C}$. The plates were washed four times (PBS) and the residual radioactivity on the wells was counted individually using a gamma scintillation counter. Specificity and sensitivity of the assay was verified using purified recombinant sTNFR (25). The sTNFR concentrations were determined in triplicates and data are expressed as mean \pm SD $(\mathrm{pg} / \mathrm{ml})$.

Northern blot analysis. Northern blot analysis of 55-kD TNFR mRNA expression was performed as previously described $(12,15,16)$. Briefly, keratinocytes were gently detached and total RNA isolated by extraction with an acid guanidinium thiocyanate phenol chloroform mixture (26). The concentration of RNA was determined from absorption at (A) $260 \mathrm{~nm}$, and A260:A280 ratios were $>1.7$. RNA ( $10 \mu \mathrm{g})$ was subjected to electrophoresis in $1.2 \%$ agarose gels containing formaldehyde (2.2 M) followed by transfer to nylon membranes (Hybond $\mathrm{N}$; Amersham-Buchler, Braunschweig, Germany). Equivalent loading and uniform transfer of RNA were assured by ethidium bromide staining of the gels before and after Northern transfer. Membranes were prehybridized $(4 \mathrm{~h})$ and hybridized (overnight) at $42^{\circ} \mathrm{C}$ with $6 \times$ SSPE: $5 \times$ Denhardt's solution: $200 \mu \mathrm{g} / \mathrm{ml}$ salmon sperm DNA. $55-\mathrm{kD}$ TNFR-specific mRNA was detected using a 2.1-kb cDNA probe (3). Control hybridizations used a cDNA probe encoding the housekeeping gene GAPDH. The cDNA fragments were biotin-14-dATP labeled by nick translation using the BioNick labeling system (Gibco/Bethesda Research Laboratories, Berlin, Germany) (27). Northern blot analysis was performed under stringent washing conditions (twice for $5 \mathrm{~min}$ using $2 \times \mathrm{SSC} / 0.5 \% \mathrm{SDS}$ at $60^{\circ} \mathrm{C}$ and once for $40 \mathrm{~min}$ using $0.1 \%$ $\mathrm{SSC} / 1 \%$ SDS at $\left.50^{\circ} \mathrm{C}\right)$. Signals were detected using the Photogene detection system (Gibco/Bethesda Research Laboratories). Autoradiography was carried out for $15 \mathrm{~min}$ at $25^{\circ} \mathrm{C}$ by using Kodak XAR films. The relative fold decrease and increase of 55-kD TNFR mRNA expression was normalized to the GAPDH mRNA control and assessed using a laser densitometer (Pharmacia LKB, Freiburg, Germany), kindly provided by Dr. P. Nielsen, Max-Planck Institut für Immunbiologie (Freiburg, Germany).

Reverse transcriptase PCR. RNA was purified from keratinocytes and $\mathrm{KB}$ cells and was then reverse transcribed using a commercially available reverse transcription kit (Pharmacia LKB). For PCR analysis, the following primer pair specific for the human 75-kD TNFR was used: 75-kD TNFR, 5' primer: CCATGGCGCCCGTCGC; 75-kD TNFR, 3' primer: GTCGCCAGTGCTCCCTTCAG. The DNA was 
amplified for 25 cycles on a DNA thermal cycler (Perkin Elmer-Cetus, Emeryville, CA). Annealing was at $52^{\circ} \mathrm{C}$ for $1 \mathrm{~min}$, extension at $72^{\circ} \mathrm{C}$ for $2 \mathrm{~min}$, and melting was at $94^{\circ} \mathrm{C}$ for $1 \mathrm{~min}$. The amplification products were visualized by ethidium bromide-stained gel analysis. RNA from 75-kD TNFR expressing HL60 cells was used as a positive control.

\section{Results}

In previous studies, cells from the human epidermoid carcinoma cell lines KB and HEp-2 were found to specifically react with anti-55-kD TNFR antibodies, but not with biologically active anti-75-kD TNFR antibodies $(7,12)$. Long-term cultured, normal human keratinocytes also failed to express $75-$ kD TNFR on their surface (12), nor was there evidence for 75-kD TNFR mRNA on Northern blot analysis (data not shown ). In the present study, this lack of 75-kD TNFR expression in human keratinocytes was corroborated by reverse transcriptase PCR (Fig. 1). Using 5' and 3' primers specific for the human 75-kD TNFR, no amplified 75-kD TNFR cDNA fragment could be detected in human keratinocytes or in cells of the epidermoid carcinoma cell line KB (Fig. 1). In contrast, RNA purified from 75-kD TNFR expressing HL-60 cells (7) contained a clearly detectable amplified fragment of reversetranscribed 75-kD cDNA (Fig. 1). These studies strongly indicate that responsiveness of human keratinocytes to TNF depends totally on 55-kD TNFR expression.

The following experiments focused on 55-kD TNFR expression and its regulation in cultured keratinocytes. The $\mathrm{mAb}$ htr-9, which specifically recognizes the ligand binding site of the 55-kD TNFR (7), significantly reacted with untreated keratinocytes (Fig. 2). Keratinocyte htr-9 reactivity was reduced after $2 \mathrm{~h}$ of TNF $\alpha$ treatment. This decrease could not be restored by acid stripping (18-20), indicating that it was due to loss of 55-kD TNFR from the keratinocyte surface, rather than competitive inhibition of htr-9 binding to keratinocytes by exogenous TNF $\alpha$. Upregulation of 55-kD TNFR surface expression was observed when keratinocytes were treated with TNF $\alpha$ for $20 \mathrm{~h}$ (Fig. 2).

Changes in 55-kD TNFR mRNA expression paralleled surface expression of the molecule (Fig. 3). There was a significant $(73 \%$ compared with untreated control) decrease in steady state levels of 55-kD TNFR mRNA expression after $2 \mathrm{~h}$ of TNF $\alpha$ stimulation. This was followed by a marked ( $180 \%$ compared with untreated control) upregulation $10 \mathrm{~h}$ later (Fig. 3 ). At this later time point, 55-kD TNFR mRNA expression in TNF $\alpha$-stimulated keratinocytes was greater than constitutive expression in unstimulated cells (Fig. 3). The observed differences in 55-kD TNFR mRNA expression between unstimulated and TNF $\alpha$-stimulated cells were not due to variations in

123

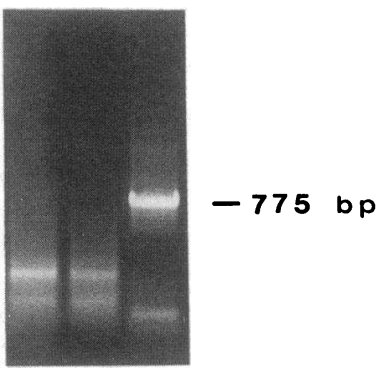

Figure 1. Detection of 75-kD TNFR mRNA by reverse transcriptase PCR. RNA from longterm cultured, normal human keratinocytes (lane 1), from KB cells (lane 2), or from HL60 cells (lane 3 ) was reverse transcribed into cDNA. Aliquots were subjected to 25 cycles of PCR in the presence of the appropriate primers (i.e., 75-kD TNFR) and visualized by gel analysis as described in Methods.

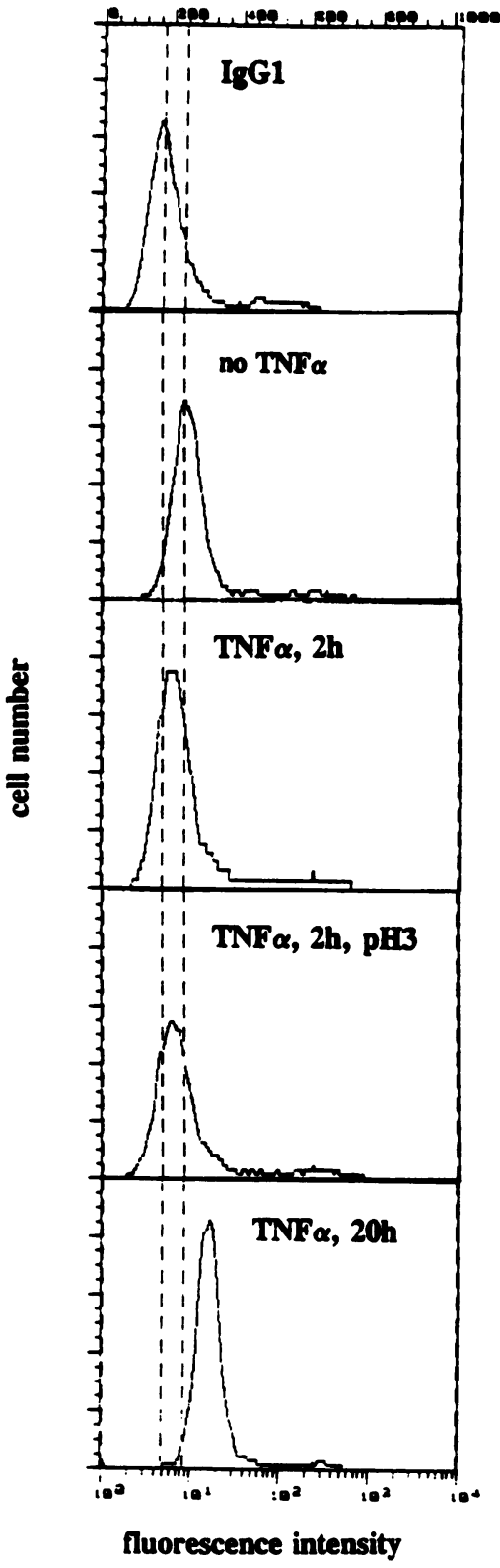

Figure 2. FACS analysis of htr-9 mAb reactivity of TNF $\alpha$-treated keratinocytes. Long-term cultured, normal human keratinocytes were either left untreated or stimulated with rhTNF $\alpha(500 \mathrm{U} / \mathrm{ml})$ and subsequently examined for htr-9 reactivity using FACS $^{\circledR}$ analysis as described in Methods. Histograms of fluorescence intensity vs. cell number represent untreated cells ( $n o T N F \alpha)$; TNF $\alpha$-stimulated cells after a 2 -h culture pe$\operatorname{riod}(T N F \alpha, 2 h) ; \mathrm{TNF} \alpha$ stimulated, $2 \mathrm{~h}$ cultured cells, which were pH 3treated before analysis (TNF $\alpha, 2 h, p H 3$ ); and TNF $\alpha$-stimulated cells, which were incubated for $20 \mathrm{~h}(T N F \alpha, 20 h)$. Use of an irrelevant mIgG1 isotype control antibody with all of the various treatment combinations showed no more fluorescence intensity than that shown for cells that were TNF $\alpha$ treated for $2 \mathrm{~h}$ and subsequently acid stripped as described in Methods (IgG1). Data represent one of five representative experiments.

the amount of total RNA, since the GAPDH housekeeping gene was equally expressed in all lanes (Fig. 3 ).

UVB radiation is a potent stimulus of human keratinocyte production and secretion of biologically active TNF $\alpha$ (21). In the following experiments, keratinocytes were exposed in vitro to $100 \mathrm{~J} / \mathrm{m}^{2} \mathrm{UVB}$ and were subsequently examined for TNFR surface expression. Unirradiated keratinocytes showed strong reactivity with $\mathrm{mAb}$ htr-9, which was significantly reduced after exposure to UVB light (Fig. 4). UVB irradiation decreased keratinocyte htr- 9 reactivity in a time-dependent manner with maximum inhibition occurring $6 \mathrm{~h}$ after exposure (Fig. 4). Essentially identical data were obtained when $\left[{ }^{125} I\right]-$ TNF $\alpha$ was used to measure keratinocyte TNFR expression (Fig. 5). Unirradiated keratinocytes specifically bound $\left[{ }^{125} \mathrm{I}\right]-$ TNF $\alpha$. Binding of $\left[{ }^{125} \mathrm{I}\right] \mathrm{TNF} \alpha$ to keratinocytes was markedly inhibited $6 \mathrm{~h}$ after exposure of cells to $100 \mathrm{~J} / \mathrm{m}^{2} \mathrm{UVB}$ (Fig. 5).

The time course of UVB-induced keratinocyte TNF $\alpha$ secretion and UVB-induced decrease in binding of [ $\left.{ }^{125} \mathrm{I}\right] \mathrm{TNF} \alpha$ to keratinocyte TNFR was consistent with a cause-effect relationship (Fig. 5). Moreover, addition of a neutralizing, polyclo- 


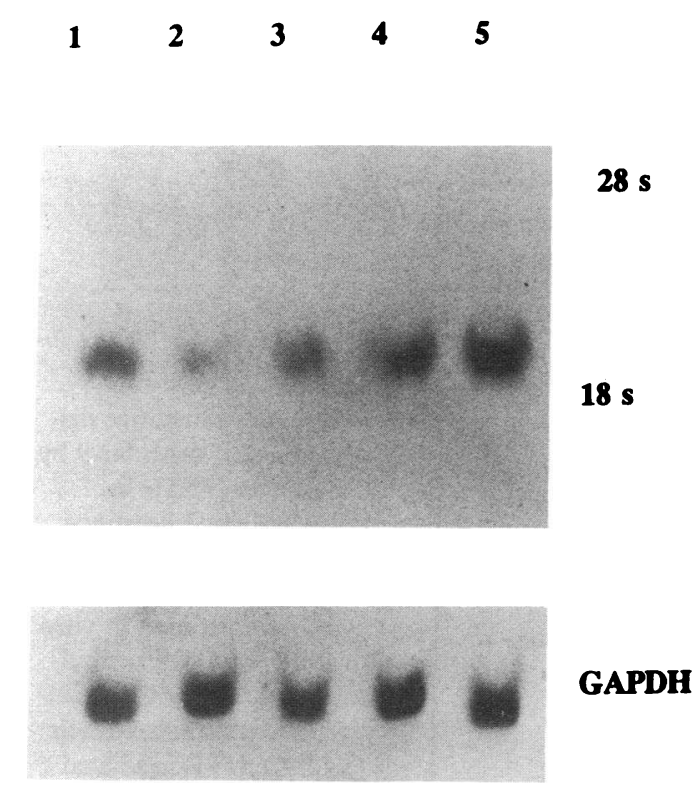

Figure 3. Northern blot analysis for the expression of mRNA specific for the 55-kD TNFR in TNF $\alpha$-stimulated keratinocytes. Long-term cultured, normal human keratinocytes were either left untreated (lane 1) or stimulated with rhTNF $\alpha(500 \mathrm{U} / \mathrm{ml})$ for $2 \mathrm{~h}$ (lane 2$), 4 \mathrm{~h}$ (lane 3 ), $6 \mathrm{~h}$ (lane 4), and $12 \mathrm{~h}$ (lane 5). Northern blot analysis of total cellular RNA ( $10 \mu \mathrm{g} / \mathrm{ml}$ ) used a biotin-labeled cDNA probe encoding for the 55-kD TNFR. A cDNA probe encoding for the housekeeping gene GAPDH served as a control. Time-dependent modulation of the expression of mRNA specific for the 55-kD TNFR could be observed in three of three experiments.

nal antibody directed against human TNF $\alpha$ to cultures with UVB-irradiated keratinocytes immediately after UVB exposure almost completely inhibited the UVB-induced decrease in htr-9 antibody binding to irradiated cells (Fig. 6). In addition, treatment of UVB-irradiated keratinocytes with glycine buffer, pH 3, 6 h after UVB exposure restored both htr-9 (Fig. 6) and [ $\left.{ }^{125} \mathrm{I}\right] \mathrm{TNF} \alpha$ (Fig. 7) binding to irradiated cells by $\sim 90 \%$, indicating the effective removal of receptor-bound TNF $\alpha$ by acid stripping. Taken together these data indicate that in vitro exposure of human keratinocytes to UVB irradiation is followed by binding of UVB-induced, endogenous TNF $\alpha$ to 55-kD TNFR on the surface of irradiated cells.

Binding of endogenous TNF $\alpha$ to irradiated keratinocytes was followed by biphasic modulation of 55-kD TNFR surface and mRNA expression. At $12 \mathrm{~h}$ after irradiation, acid stripping only partially $(\sim 20-30 \%)$ restored decreased binding of $\left[{ }^{125} \mathrm{I}\right]-$ TNF $\alpha$ to UVB-irradiated keratinocytes, indicating a loss of TNFR from the surface of irradiated cells at this later time point (Fig. 7). $24 \mathrm{~h}$ after irradiation, htr-9 as well as [ $\left.{ }^{125} \mathrm{I}\right]-$ TNF $\alpha$ reactivity of UVB-irradiated keratinocytes was restored even without acid stripping, indicating that 55-kD TNFR were reexpressed. TNFR reexpression could be almost completely inhibited with sublethal doses of cycloheximide (Fig. 7). In addition to modulation of TNFR surface expression, $55-\mathrm{kD}$ TNFR mRNA expression was found to be affected by UVB light. As is shown in Fig. 8, unirradiated keratinocytes expressed clearly detectable amounts of 55-kD TNFR mRNA. 6 $h$ after UVB irradiation, TNFR mRNA steady state levels were significantly ( $87 \%$ compared with untreated control) decreased, but 12-24 $\mathrm{h}$ after UVB exposure, 55-kD TNFR mRNA reexpression occurred (Fig. 8). At 48 h, TNFR mRNA

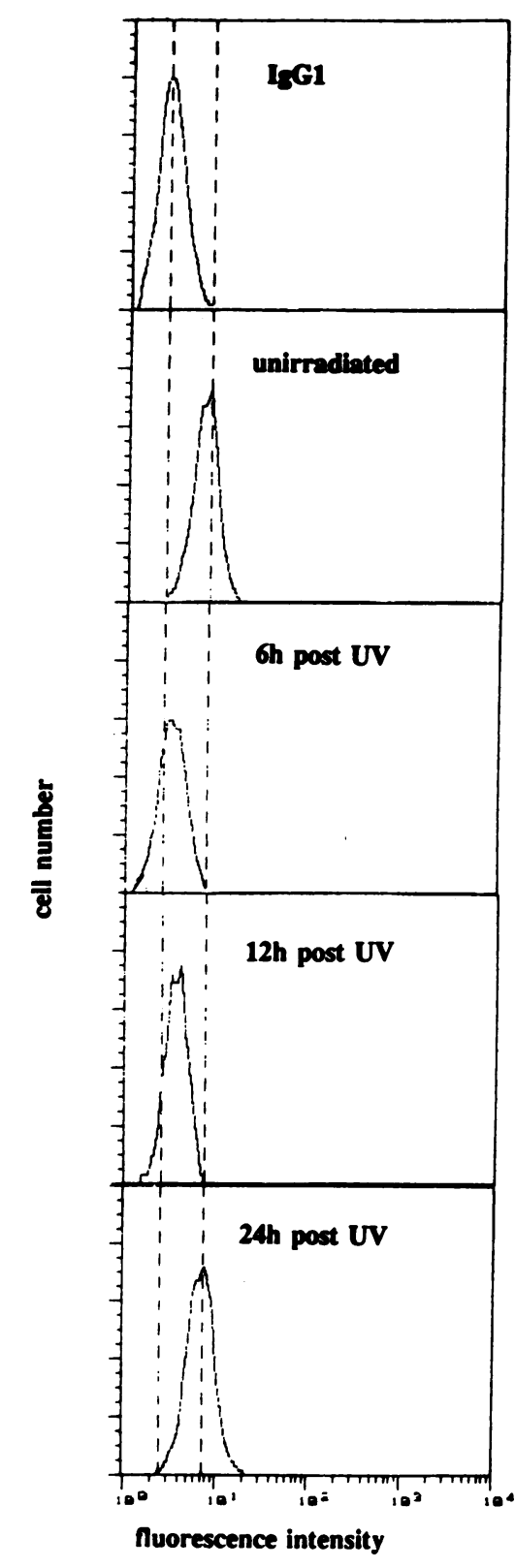

Figure 4. FACS ${ }^{\otimes}$ analysis of htr-9 $\mathrm{mAb}$ reactivity of UVB-irradiated keratinocytes. Longterm cultured, normal human keratinocytes were either left untreated (unirradiated) or exposed in vitro to $100 \mathrm{~J} / \mathrm{m}^{2}$ UVB (UV) and subsequently examined for htr- $9 \mathrm{mAb}$ reactivity at the indicated time points by FACS ${ }^{\otimes}$ analysis as described in Methods. Reactivity of unirradiated cells with mAb htr-9 did not change during the entire duration of the culture period (shown for $6 \mathrm{~h}$ : unirradiated). Use of an irrelevant mIgG1 isotype control antibody with all of the various treatment conditions showed no more fluorescence intensity than that shown for unirradiated cells, which had been incubated for $6 \mathrm{~h}$ (IgGl). Data are given as histograms of fluorescence intensity vs. cell number and represent one of five essentially identical experiments.

expression in UVB-irradiated cells exceeded that observed in unirradiated cells (Fig. 8; 210\% increase compared with untreated control). Similarly, binding of $\left[{ }^{125} I\right] T N F \alpha$ to UVBirradiated keratinocytes was clearly greater than that observed to these cells before UVB treatment (Fig. 7). Biphasic modulation of 55-kD TNFR surface expression could be effectively blocked by adding neutralizing anti-TNF $\alpha$ antibodies to UVBirradiated keratinocytes. As is shown in Fig. 9, constitutive htr9 reactivity was significantly reduced in UVB-irradiated cells $12 \mathrm{~h}$ after exposure, and this decrease was completely inhibited if anti-TNF $\alpha$ antibodies were added to cultures immediately after irradiation. Similarly, $48 \mathrm{~h}$ after UVB irradiation, a significant increase in htr- 9 reactivity could be observed, which could be specifically blocked if irradiated cells were cultured in the presence of anti-TNF $\alpha$ antibodies (Fig. 9).

In addition to membrane-associated forms, soluble forms of the 55- and 75-kD TNFR recently have been identified (2225 ). Supernatants of human keratinocytes were found to contain significant amounts of soluble $55-\mathrm{kD}$, but not of soluble 


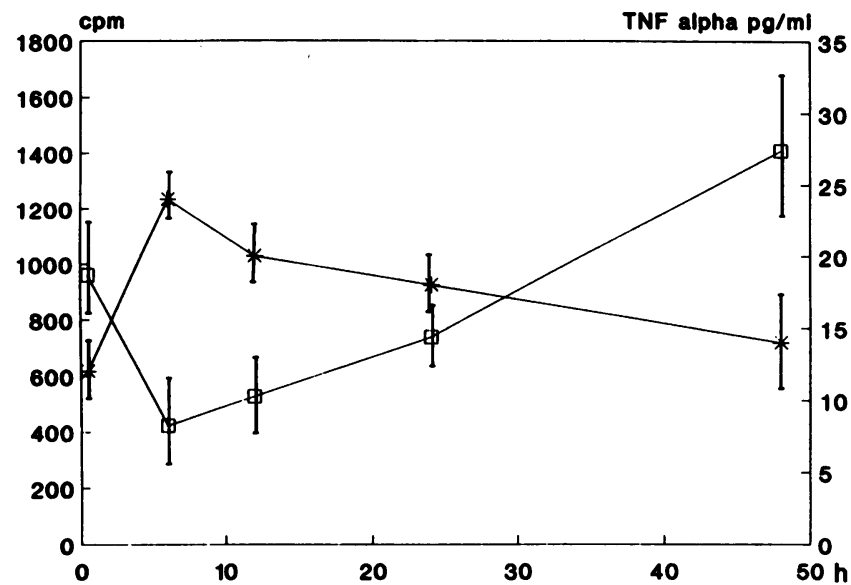

Figure 5. Effects of UVB light on human keratinocyte TNF $\alpha$ secretion and surface binding of $\left[{ }^{125} \mathrm{I}\right] \mathrm{TNF} \alpha$. Long-term cultured, normal human keratinocytes were exposed in vitro to $100 \mathrm{~J} / \mathrm{m}^{2} \mathrm{UVB}$ and subsequently assessed for their capacity to release TNF $\alpha$ into culture supernatant $\left({ }^{*}\right)$ or to bind $\left[{ }^{125} \mathrm{I}\right] \mathrm{TNF} \alpha(\square)$ at the time points indicated $(0-48 \mathrm{~h})$. The amount of TNF $\alpha$ present in supernatants of KC was determined by means of a TNF $\alpha$-specific ELISA as described in Methods. In cultures of unirradiated control cells, TNF $\alpha$ concentrations did not exceed $15 \mathrm{pg} / \mathrm{ml}$ over the entire 48-h incubation period (data not shown). Data represent mean \pm SD of three representative experiments. Binding of $\left[{ }^{125} \mathrm{I}\right] \mathrm{TNF} \alpha$ to UVB-irradiated KC was determined as described in Methods. Data are given as cpm of specific binding, which was calculated by subtracting nonspecific binding from total binding and represent mean \pm SD of three representative experiments.

75-kD TNFR (Fig. 10). In contrast to membrane expression, production of soluble 55-kD TNFR remained unaffected upon stimulation of cells with rhTNF $\alpha$ or exposure to UVB irradiation (Fig. 10).

\section{Discussion}

The present study demonstrates 55-kD TNFR surface as well as mRNA expression in human keratinocytes, thus confirming previous results (12). In marked contrast to $55-\mathrm{kD}, 75-\mathrm{kD}$ TNFR expression could not be detected in human keratinocytes, even when the highly sensitive method of reverse transcriptase PCR was used. Lack of 75-kD TNFR expression was not confined to resting keratinocytes, since similar data were obtained if 75-kD TNFR expression was assessed in human keratinocytes, which had been activated by stimulation with $\operatorname{rhTNF} \alpha$ or exposure to $100 \mathrm{~J} / \mathrm{m}^{2} \mathrm{UVB}$ (data not shown). Moreover, when supernatants of human keratinocytes were assessed for soluble TNFR, significant amounts of soluble 55kD TNFR, but not even trace amounts of soluble 75-kD TNFR, could be detected. These observations further support the concept that in contrast to human leukocytes, which express both types of TNFR, epithelial cells such as keratinocytes express only the 55-kD TNFR. Taken together, these studies strongly indicate that, at least under the conditions tested, responsiveness of human epidermal keratinocytes to TNF $\alpha$ is critically dependent on regulation of 55-kD TNFR expression.

Human keratinocyte 55-kD TNFR expression was found to be regulated in vitro by rhTNF $\alpha$. Regulation of a receptor by its physiological ligand is not unique for TNF $\alpha$, as it has previously been observed for several other cytokines, including IL-6 $(28,29)$. When long-term cultured normal human keratino-

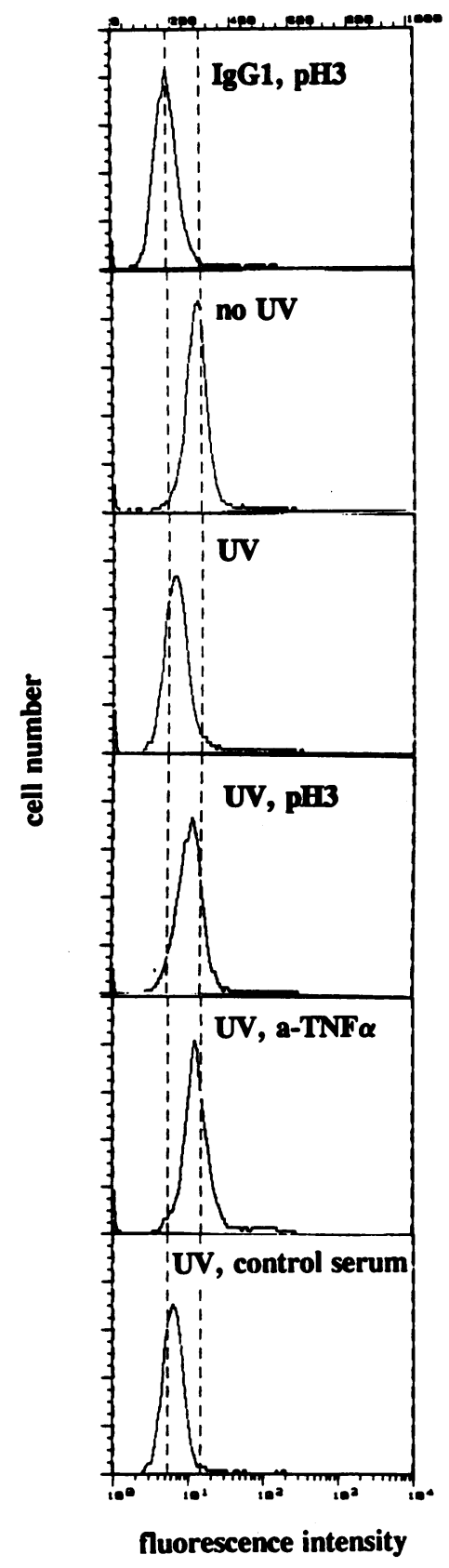

Figure 6. Competitive displacement of mAb htr- 9 by endogenous TNF $\alpha$ in UVB-irradiated keratinocytes. Long-term cultured, normal human keratinocytes were exposed in vitro to $100 \mathrm{~J} / \mathrm{m}^{2} \mathrm{UVB}$ and cultured for $6 \mathrm{~h}$. FACS $^{\oplus}$ analysis used unirradiated cells ( $n o U V$ ); UVB-irradiated cells without additional treatment ( $U V)$; UVB-irradiated cells that were $\mathrm{pH}$ 3-glycine buffer treated before FACS ${ }^{\oplus}$ analysis ( $U V$, pH 3); UVB-irradiated cells that were incubated in the presence of a polyclonal rabbit anti-TNF $\alpha$ antibody $(U V, a-T N F \alpha)$; or UVBirradiated cells that were incubated in the presence of an equivalent dilution of a rabbit control serum ( $U V$, control serum). IgG1 control stainings were done for all variables and did not exceed background fluorescence (shown for irradiated, pH 3-treated cells: $I g G 1$ ). Data are given as histograms of fluorescence intensity vs. cell number and represent one of three essentially identical experiments.

cytes were replaced in these studies by cells from the epidermoid carcinoma cell line KB, an essentially identical TNF $\alpha$ induced biphasic modulation of 55-kD TNFR expression could be observed (data not shown). However, the capacity of TNF $\alpha$ to regulate $55-\mathrm{kD}$ TNFR expression may be relatively specific for keratinocytes, since TNF $\alpha$ failed to affect steady state levels of 55-kD TNFR mRNA in hematopietic cells or cells from the lung carcinoma cell line A549 $(4,30)$. On the other hand, TNF $\alpha$ may also affect expression of the human 75-kD TNFR, because immunohistochemical studies have demonstrated increased expression of 75-kD TNFR protein on the surface of epitheloid and giant cells in hyperplastic human lymphoid tissue concomitant with increased TNF $\alpha$ immunoreactivity (31).

TNF $\alpha$ initially caused a marked decrease in 55-kD TNFR surface expression. Downregulation of 55-kD TNFR expression in TNF $\alpha$-treated human keratinocytes may have been due 


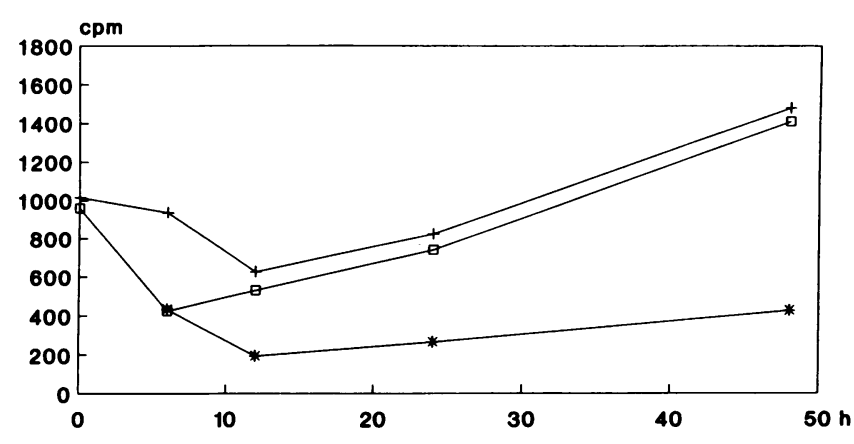

Figure 7. Binding of $\left[{ }^{125} \mathrm{I}\right] \mathrm{TNF} \alpha$ to UVB-irradiated keratinocytes. Long-term cultured, normal human keratinocytes were exposed in vitro to $100 \mathrm{~J} / \mathrm{m}^{2}$ UVB and subsequently cultured in the absence ( $\square$ ) or presence of cycloheximide $\left({ }^{*}\right)$. Specific binding of $\left[{ }^{125} \mathrm{I}\right] \mathrm{TNF} \alpha$ to UVB-irradiated keratinocytes without ( $\square$ ) or with pH 3 treatment (+) before incubation with [ ${ }^{125}$ I]TNF $\alpha$ was determined at the indicated time points as described in Methods. Data are given as cpm of specific binding, which were obtained by subtracting unspecific binding from total binding and represent one of three essentially identical experiments.

to receptor shedding, as appears to be the case for the decrease in TNF-binding capacity of phorbol myristate acetate-treated leukocytes (32). However, supernatants of TNF $\alpha$-treated keratinocytes did not contain increased levels of soluble $55-\mathrm{kD}$ TNFR compared with resting cells. Previous studies indicate that binding of TNF $\alpha$ to keratinocyte TNFR at $34^{\circ} \mathrm{C}$ is followed by a rapid internalization of TNF $\alpha$-TNFR complexes (17). This is in agreement with our own observation that both unirradiated and UVB-irradiated keratinocytes are capable of

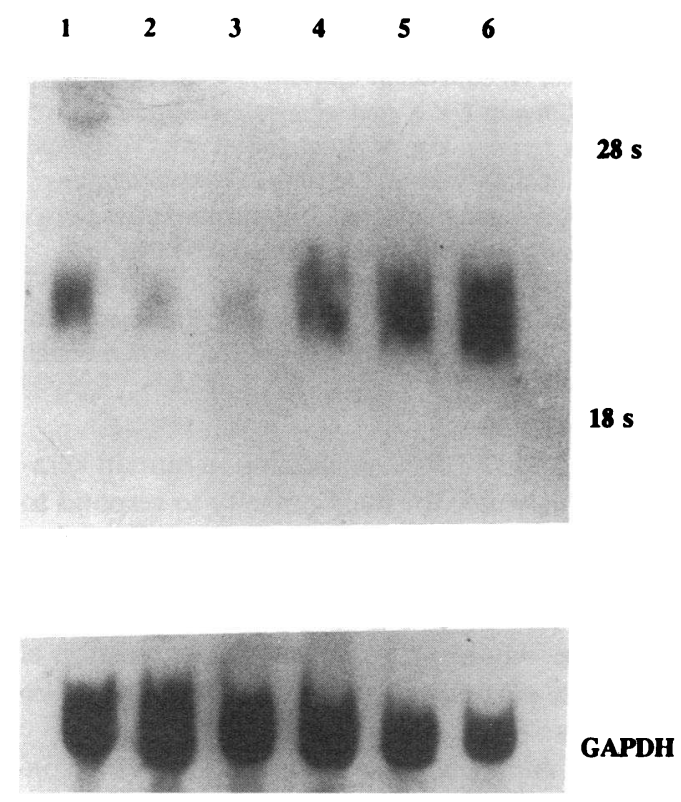

Figure 8. Northern blot analysis for the expression of mRNA specific for the 55-kD TNFR in UVB-irradiated keratinocytes. Long-term cultured, normal human keratinocytes were either left untreated (lane 1) or exposed in vitro to $100 \mathrm{~J} / \mathrm{m}^{2} \mathrm{UVB}$ and cultured for $4 \mathrm{~h}$ (lane 2), $6 \mathrm{~h}$ (lane 3), $12 \mathrm{~h}$ (lane 4), $24 \mathrm{~h}$ (lane 5), or $48 \mathrm{~h}$ (lane 6) after UVB exposure. Northern blot analysis of total cellular RNA ( $10 \mu \mathrm{g})$ used a Biotin-labeled cDNA probe encoding for the 55-kD TNFR. A cDNA probe encoding for the housekeeping gene GAPDH served as a control. internalizing $90 \%$ of receptor-bound [ $\left.{ }^{125} \mathrm{I}\right] \mathrm{TNF} \alpha$ within 45 min, if kept at $37^{\circ} \mathrm{C}$ (data not shown). Thus, initial loss of TNFR from the surface of TNF $\alpha$-treated or UVB-irradiated cells is most likely due to internalization of TNF $\alpha$-TNFR complexes. However, the present observation, that downregulation of TNFR surface expression is associated with a reduction in 55-kD TNFR mRNA to almost background levels, indicates the presence of a feedback mechanism, which may decrease keratinocyte TNFR expression by affecting 55-kD TNFR transcription. Similarly, differentiation of HL60 cells into macrophage-like cells recently was found to be associated with a reduction of both 55-kD TNFR surface and mRNA expression (33).

Downregulation of 55-kD TNFR surface expression in TNF $\alpha$-stimulated cells was followed by TNFR reexpression and induction, respectively, and these changes were associated with alterations of 55-kD TNFR mRNA expression. TNF $\alpha$ induced TNFR reexpression could be significantly inhibited in UVB-irradiated keratinocytes, if cells were treated with sublethal concentrations of the protein synthesis inhibitor cycloheximide. This indicates that TNF $\alpha$-induced TNFR reexpression and induction is due to newly synthesized rather than recycled receptor molecules. Further studies will have to determine whether the observed alterations in steady state levels of 55-kD TNFR mRNA expression are due to alterations in the transcription rate or caused by posttranscriptional mechanisms.

In vitro exposure of human keratinocytes to UVB radiation was previously found to significantly stimulate de novo synthesis and secretion of TNF $\alpha$ (21). This finding was confirmed and extended in the present study. UVB-induced endogenous TNF $\alpha$ bound to 55-kD TNFR on the surface of irradiated keratinocytes or KB cells (data not shown), suggesting an autocrine regulatory mechanism. This assumption is strongly supported by the observation that binding of UVB-induced endogenous TNF $\alpha$ to keratinocyte TNFR induced a biphasic modulation of 55-kD TNFR surface and mRNA expression in irradiated keratinocytes, which closely resembled that observed in unirradiated cells that had been stimulated with exogenous rhTNF $\alpha$. Significant downregulation of TNFR surface and mRNA expression by endogenous TNF $\alpha$ in UVB-irradiated cells occurred $12 \mathrm{~h}$ after UVB exposure, whereas downregulation of 55-kD TNFR surface and mRNA expression in unirradiated cells that had been stimulated with exogenous rhTNF $\alpha$ could already be observed after a $2-h$ incubation period. These kinetic differences may partially be explained by the requirement for de novo synthesis and secretion of TNF $\alpha$ in cultures with UVB-irradiated cells. Moreover, the amount of TNF $\alpha$ produced by UVB-irradiated keratinocytes is considerably less (100-200-fold) than that added exogenously to unirradiated cells, and this may represent an additional factor contributing to the observed kinetic differences.

The capacity of UVB-induced endogenous TNF $\alpha$ to exert autocrine regulatory events through binding to keratinocyte 55-kD TNFR may not be restricted to modulation of 55-kD TNFR surface and mRNA expression. Recent studies using cells from the epidermoid carcinoma cell line $\mathrm{KB}$ indicate that UVB-induced production of prostaglandin E2 is at least partially mediated by UVB-induced endogenous TNF $\alpha$, acting through $55-\mathrm{kD}$ TNFR on the surface of irradiated KB cells (34). These studies indicate that UVB radiation-induced intraepidermal production and secretion of keratinocyte-derived 


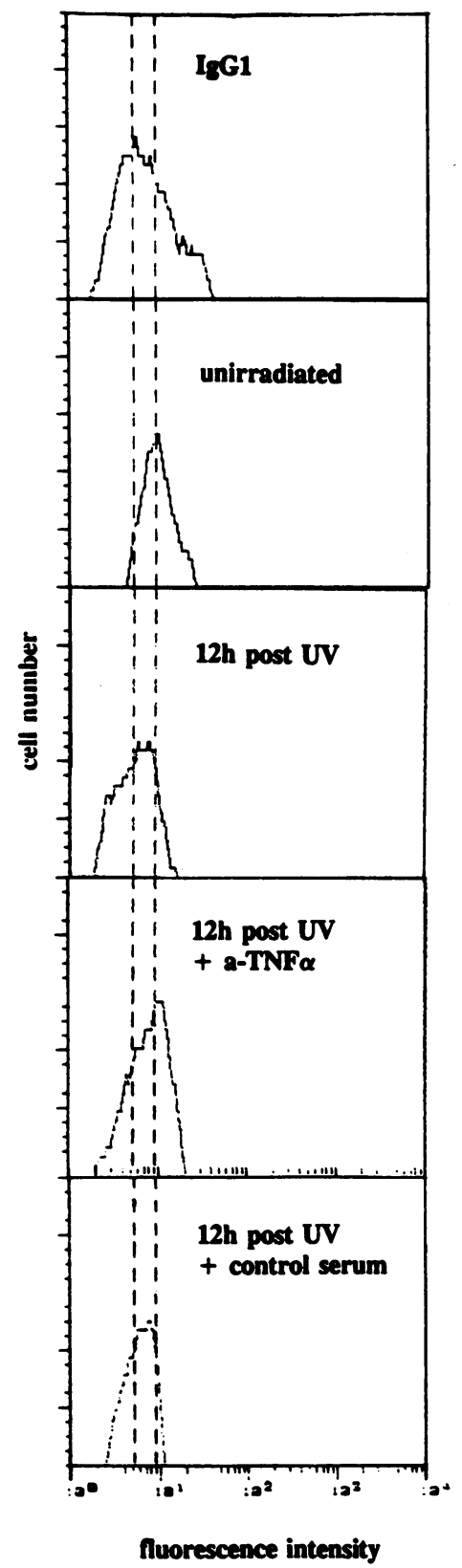

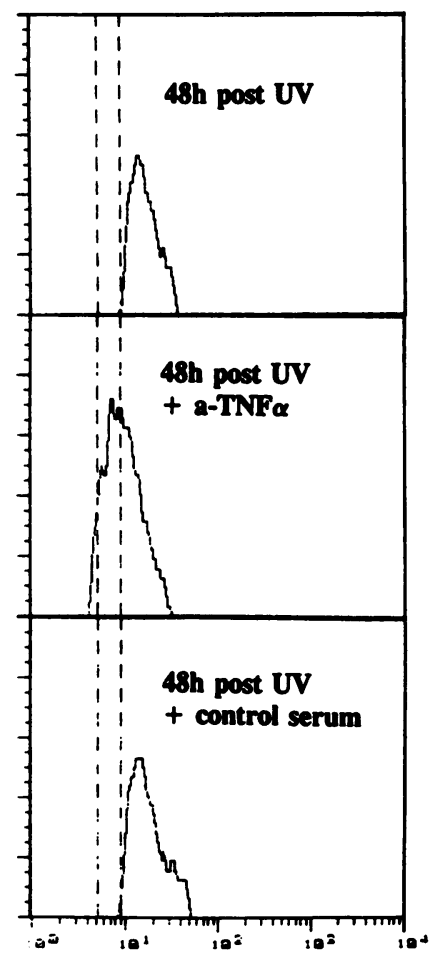

Figure 9. FACS ${ }^{\oplus}$ analysis of htr-9 mAb reactivity of UVB-irradiated keratinocytes. Long-term cultured, normal human keratinocytes were either left unirradiated or exposed in vitro to $100 \mathrm{~J} / \mathrm{m}^{2} \mathrm{UVB}$ and incubated for 12 or $48 \mathrm{~h}$. FACS analysis used unirradiated cells (unirradiated); UVB-irradiated cells without additional treatment ( $12 \mathrm{~h}$ post $U V ; 48 \mathrm{~h}$ post $U V$ ); UVB-irradiated cells that were incubated in the presence of a polyclonal rabbit anti-TNF $\alpha$ antibody ( $12 h$ post $U V+a-T N F \alpha ; 48 h$ post $U V+a-T N F \alpha)$; or UVB-irradiated cells that were cultured in the presence of an equivalent dilution of a rabbit control serum ( $12 \mathrm{~h}$ post $U V+$ control serum; $48 \mathrm{~h}$ post $U V$ + control serum). Use of an irrelevant mIgGl isotype control antibody with all the various treatment combinations did not show more fluorescence intensity than that shown for UVB-irradiated cells that had been cultured for $12 \mathrm{~h}(I g G 1)$. Data are given as histograms of fluorescence intensity vs. cell number and represent one of two essentially identical experiments. cytokines (35) may not only exert paracrine (36), but also autocrine, regulatory effects.

The functional relevance of human keratinocyte $55-\mathrm{kD}$ TNFR expression was proven in studies, demonstrating that this receptor molecule plays a pivotal role in regulation of TNF $\alpha$-induced human keratinocyte ICAM-1 expression (12). TNF $\alpha$-induced keratinocyte ICAM- 1 expression is affected by in vitro UVB exposure $(15,16)$. Specifically, exposure of keratinocytes to $100 \mathrm{~J} / \mathrm{m}^{2}$ UVB inhibited TNF $\alpha$-induced ICAM-1 expression, if irradiated cells were TNF $\alpha$ stimulated within the first $12 \mathrm{~h}$ after UVB exposure. In contrast, 24-48 $\mathrm{h}$ after UVB irradiation, TNF $\alpha$ responsiveness, as assessed by TNF $\alpha$-induced ICAM-1 expression, was found to be restored (16). Biphasic modulation of TNF $\alpha$-induced keratinocyte ICAM-1 expression and of keratinocyte 55-kD TNFR expression were caused by identical doses of UVB light, and the time courses of both UVB-induced regulatory events are consistent with a cause-effect relationship. It is therefore proposed that UVB-in- duced modulation of 55-kD TNFR expression in human keratinocytes may be of relevance for their capacity to respond to TNF $\alpha$, because downregulation of 55-kD TNFR expression may contribute to the failure of UVB-irradiated, TNF $\alpha$ stimulated keratinocytes to upregulate ICAM-1 molecules 0-12 h after exposure, whereas 55-kD TNFR reexpression at 24-48 h may at least partially explain restoration of TNF $\alpha$ responsiveness in irradiated cells.

It is currently not known whether upregulation above constitutive levels of 55-kD TNFR expression by TNF $\alpha$ treatment or UVB irradiation is associated with an increased sensitivity of keratinocytes towards TNF $\alpha$. It should be noted, however, that TNF $\alpha$ restimulation of UVB-irradiated $48-h$-cultured KB cells (16) or long-term cultured normal human keratinocytes (data not shown ) with rhTNF $\alpha$ failed to further increase UVB radiation-induced ICAM-1 expression (16). Similarly, TNF $\alpha$ restimulation of TNF $\alpha$-pretreated keratinocytes did not further increase ICAM-1 expression compared with TNF $\alpha$ restimu- 


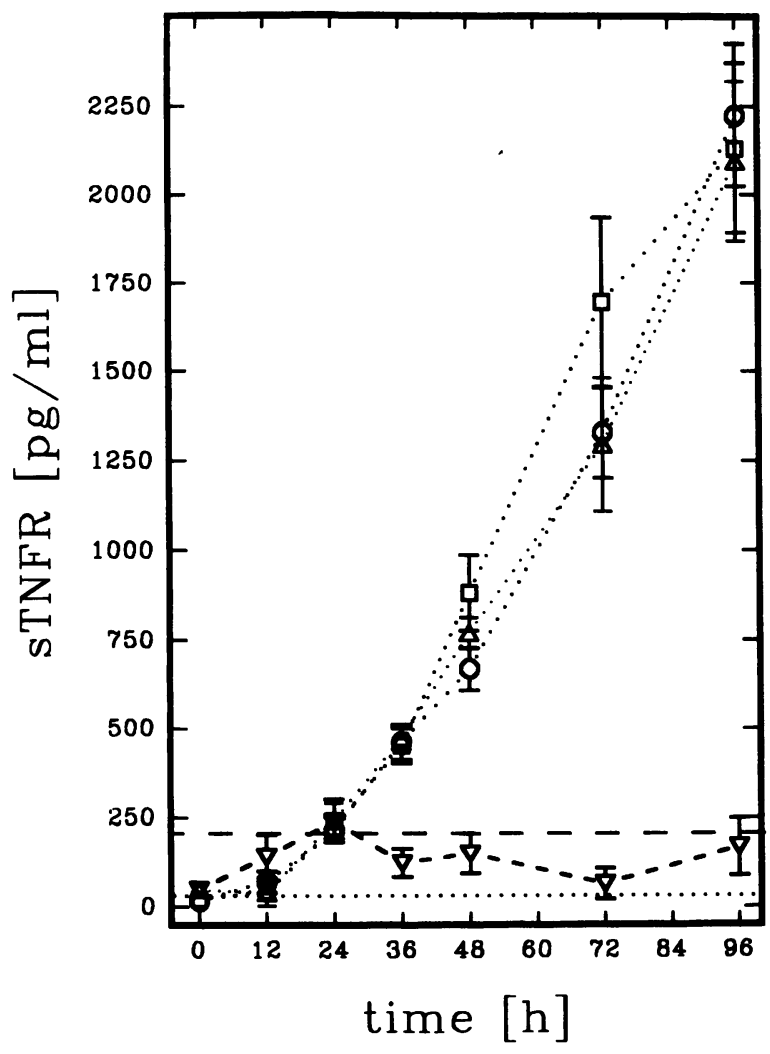

Figure 10. Detection of soluble (s) 55-kD and s75-kD TNFR in supernatants derived from human keratinocytes. Supernatants were harvested from long-term cultured, normal human keratinocytes (2.5 $\times 10^{5}$ cells per tissue culture plate) at the indicated time points, centrifuged for $5 \mathrm{~min}$ at $10,000 \mathrm{~g}$ to remove any cell particles, and stored until assay at $-20^{\circ} \mathrm{C}$. The amount of s55-kD $(\cdots)$ and $s 75-k D$ $(--)$ TNFR in cell-free supernatants derived from untreated $(\square)$, TNF $\alpha$-stimulated (O), or UVB-irradiated $(\Delta)$ cells was determined as described in Methods. The background for detection of s55kDTNFR was $40 \mathrm{pg} / \mathrm{ml} \mathrm{( \cdots )}$ and for s75-kD TNFR (- - ) $200 \mathrm{pg} / \mathrm{ml}$ as indicated. All measurements were done in triplicates. Data are given as mean $\pm \mathrm{SD}(\mathrm{pg} / \mathrm{ml})$ and represent one of three essentially identical experiments.

lated cells that had not been TNF $\alpha$ prestimulated (data not shown). These studies indicate that increased expression of 55-kD TNFR expression may not necessarily be associated with an enhanced capacity of keratinocytes to respond to TNF $\alpha$. Thus, increased 55-kD TNFR membrane expression may not further increase sensitivity of keratinocytes towards TNF $\alpha$ but rather serve to trap TNF $\alpha$ molecules. In the in vivo situation, this mechanism may eventually protect $\mathrm{TNF} \alpha$ sensitive epidermal cells distinct from keratinocytes, such as Langerhans cells $(37,38)$.

In summary, these studies provide clear evidence that human keratinocytes exclusively express the 55-kD TNFR and that expression of this receptor molecule may be regulated in this cell type by TNF $\alpha$ and UVB light, respectively. To the best of our knowledge, this is the first report demonstrating a biphasic modulation of 55-kD TNFR surface and mRNA expression in human cells. Further studies will clarify the effects of UVB irradiation in vivo on keratinocyte TNFR expression in situ as well as the relevance of TNF $\alpha$-induced regulation of keratinocyte 55-kD TNFR expression with respect to TNF $\alpha$-mediated inflammatory skin reactions, such as allergic contact dermatitis $(39,40)$.

\section{Acknowledgments}

The authors thank Dr. Craig A. Elmets, for critically reading the manuscript.

This work was supported by a grant from the Deutsche Forschungsgemeinschaft ( $\mathrm{Kr} 871 / 3-2$ and $\mathrm{Lu}$ 443/1-1) and the Volkswagen Stiftung I/67 420. H. Christoph has been supported by grant $\mathrm{Ch} 121 / 1-1$ from the Deutsche Forschungsgemeinschaft.

\section{References}

1. Loetscher, H., M. Steinmetz, and W. Lesslauer. 1991. Tumor necrosis factor: receptors and inhibitors. Cancer Cells (Cold Spring Harbor). 3:221-226.

2. Sprang, S. R. 1990. The divergent receptors for TNF. Trends Biol. Sci. 15:366-368.

3. Loetscher, H., Y. E. Pan, H. W. Lahm, R. Gentz, M. Brockhaus, H. Tabuchi, and W. Lesslauer. 1990. Molecular cloning and expression of the human 55kD tumor necrosis factor receptor. Cell. 61:351-359.

4. Schall, T. J., M. Lewis, K. J. Koller, A. Lee, G. C. Rice, G. H. W. Wong, T. Gatanaga, G. A. Granger, R. Lentz, H. Raab, et al. 1990. Molecular cloning and expression of a receptor for human tumor necrosis factor. Cell. 61:361-370.

5. Smith, C. A., T. Davis, T. Anderson, L. Solam, M. P. Beckmann, R. Jerzy, S. K. Dower, D. Cosman, and R. G. Goodwin. 1990. A receptor for tumor necrosis factor defines an unusual family of cellular and viral proteins. Science (Wash. DC). 248:1019-1022.

6. Dembic, Z., H. Loetscher, U. Gubler, Y. E. Pan, H. Lahm, R. Gentz, M. Brockhaus, and $W$. Lesslauer. 1990. Two human TNF receptors have similar extracellular, but distinct intracellular domain sequences. Cytokines. 2:231-237.

7. Brockhaus, M., H. J. Schoenfeld, E. J. Schlaeger, W. Hunziker, W. Lesslauer, and H. Loetscher. 1990. Identification of two types of tumor necrosis factor receptors on human cell lines by monoclonal antibodies. Proc. Natl. Acad. Sci. USA. 87:3127-3131.

8. Kalthoff, H., C. Roeder, M. Brockhaus, H.-G., Thiele, and W. Schmiegel. 1993. Tumor necrosis factor (TNF) up-regulates the expression of p75 but not p55 TNF receptors, and both receptors mediate, independently of each other, up-regulation of transforming growth factor $\alpha$ and epidermal growth factor mRNA. J. Biol. Chem. In press.

9. Tartaglia, L. A., R. F. Weber, I. S. Figari, C. Reynolds, M. A. Palladino, Jr., and D. V. Goeddel. 1991. The two different receptors for tumor necrosis factor mediate distinct cellular responses. Proc. Natl. Acad. Sci. USA. 88:9292-9296.

10. Hohmann, H. P., M. Brockhaus, P. A. Baeuerle, R. Remy, R. Kolbeck, and A. P. G. M. van Loon. 1990. Expression of the types A and B tumor necrosis factor (TNF) is independently regulated, and both receptors mediate activation of the transcription factor NF-kB. J. Biol. Chem. 265:22409-22417.

11. Gehr, G., R. Gentz, M. Brockhaus, H. Loetscher, and W. Lesslauer. 1992. Both tumor necrosis factor receptor types mediate proliferative signals in human mononuclear cell activation. J. Immunol. 149:911-917.

12. Trefzer, U., M. Brockhaus, H. Loetscher, F. Parlow, A. Kapp, E. Schöpf, and J. Krutmann. 1991. 55-kd tumor necrosis factor receptor is expressed by human keratinocytes and plays a pivotal role in regulation of human keratinocyte ICAM-1 expression. J. Invest. Dermatol. 97:911-916.

13. Kupper, T. 1989. Mechanisms of cutaneous inflammation. Arch. Derma tol. $125: 1406-1411$.

14. Krutmann, J. 1992. Pharmacological aspects of ICAM-1 regulation in the skin. In Pharmacology of the Skin. H. Mukthar, editor. CRC Press Inc., Boca Raton, FL. 316-328.

15. Krutmann, J., A. Köck, E., Schauer, F. Parlow, A. Möller, A. Kapp, E. Schöpf, and T. A. Luger. 1990. Tumor necrosis factor beta and ultraviolet radiation are potent regulators of human keratinocyte ICAM-1 expression. J. Invest. Dermatol. 95:127-131.

16. Krutmann, J., W. Czech, F. Parlow, U. Trefzer, A. Kapp, E. Schöpf, and T. A. Luger. 1992. Ultraviolet radiation effects on human keratinocyte ICAM-1 expression: UV-induced inhibition of cytokine-induced ICAM-1 mRNA expression is transient, differentially restored for IFN $\gamma$ versus TNF $\alpha$, and followed by ICAM-1 induction via a TNF $\alpha$-like pathway. J. Invest. Dermatol. 98:923-928.

17. Pillai, S., D. D. Bikle, T. E. Eessalu, B. B. Aggarwal, and P. M. Elias. 1989. Binding and biological effects of tumor necrosis factor alpha on cultured neonatal foreskin keratinocytes. J. Clin. Invest. 83:816-821.

18. Tsujimoto, M., and J. Vilcek. 1986. Tumor necrosis factor receptors in HeLa cells and their regulation by interferon- $\gamma$. J. Biol. Chem. 261:5384-5388.

19. Yoshie, O., K. Tada, and N. Ishida. 1987. Binding and crosslinking of ${ }^{125}$ I-labeled recombinant human tumor necrosis factor to cell surface receptors. $J$. Biochem. 100:531-541. 
20. Tsujimoto, M., and J. Vilcek. 1987. Tumor necrosis factor-induced downregulation of its receptors in HeLa cells. J. Biochem. 102:1571-1577.

21. Köck, A., T. Schwarz, R. Kirnbauer, A. Urbanski, P. Perry, J. C. Ansel and T. A. Luger. 1990. Human keratinocytes are a source for tumor necrosis factor $\alpha$. Evidence for synthesis and release upon stimulation with endotoxin or ultraviolet light. J. Exp. Med. 172:1609-1614.

22. Porteu, F., M. Brockhaus, D. Wallach, H. Engelmann, and C. F. Nathan. 1991. Human neutrophil elastase releases a ligand-binding fragment from the 75-kDa tumor necrosis factor (TNF) receptor: comparison with the proteolytic activity responsible for shedding of the TNF receptors from stimulated neutrophils. J. Biol. Chem. 266:18846-18853.

23. Digel, W., F. Porszolt, M. Schmid, F. Herrmann, W. Lesslauer, and M. Brockhaus. 1992. High levels of circulating soluble receptors for tumor necrosis factor in B-cell malignancies. J. Clin. Invest. 89:1690-1693.

24. Spinas, G., F. Keller, and M. Brockhaus. 1992. Release of soluble receptors for tumor necrosis factor (TNF) in relation to circulating TNF during experimental endotoxinemia. J. Clin. Invest. 90:533-536.

25. Loetscher, H., R. Gentz, M. Zuluaf, A. Lustig, H. Tabucchi, J. Schlaeger, M. Brockhaus, H. Gallati, M. Manneberg, and W. Lesslauer. 1991. Recombinant 55-kDa tumor necrosis factor (TNF) receptor. Stoichiometry of binding to TNFa and TNF $\beta$ and inhibition of TNF activity. J. Biol. Chem. 266:18324-18329.

26. Chomzynski, P., and N. Sacchi. 1987. Single-step method of RNA isolation by acid guanidinium thiocyanate-phenol-chloroform extraction. Ann. Biochem. 162:156-159.

27. Gebeyehu, G., P. Y. Rao, P. SooChan, D. A. Simms, and L. Klevan. 1987. Novel biotinylated nucleotide-analogs for labeling and colorimetric detection of DNA. Nucleic Acid. Res. 15:4513-4534.

28. Bauer, J., T. M. Bauer, T. Kalb, T. Taga, G. Lengyel, T. Hirano, T. Kishimoto, G. Acs, L. Mayer, and W. Gerok. 1989. Regulation of interleukin 6 receptor expression in human monocytes and monocyte-derived macrophages. Comparison with the expression in human hepatocytes. J. Exp. Med. 170:15371549.

29. Zohlnhöfer, D., L. Graeve, S. Rose-John, H. Schooltink, E. Dittrich, and P. C. Heinrich. 1992. The hepatic interleukin-6 receptor. Down-regulation of the interleukin-6 binding subunit ( $\mathrm{gp} 80$ ) by its ligand. FEBS (Fed. Eur. Biochem. Soc.). 306:219.
30. Lindvall, L., M. Lantz, U. Gullberg, and I. Olsson. 1990. Modulation of the constitutive gene expression of the $55 \mathrm{KD}$ tumor necrosis factor receptor in hematopoietic cells. Biochem. Biophys. Res. Commun. 172:557-563.

31. Ryffel, B., M. Brockhaus, U. Dürmüller, and F. Gudat. 1991. Tumor necrosis factor receptors in lymphoid tissues and lymphomas. Am. J. Pathol. 139:7-15.

32. Porteu, F., and C. Nathan. 1990. Shedding of tumor necrosis factor receptors by activated human neutrophils. J. Exp. Med. 172:599-607.

33. Winzen, R., D. Wallach, H. Engelmann, Y. Nophar, C. Brakebusch, O. Kemper, K. Resch, and H. Holtmann. 1992. Selective decrease in cell surface expression and mRNA level of the 55-kDa tumor necrosis factor receptor during differentiation of HL-60 cells into macrophage-like but not granulocyte-like cells. J. Immunol. 148:3454-3460.

34. Grewe, M., U. Trefzer, M. Brockhaus, A. Kapp, E. Schöpf, and J. Krutmann. 1992. Analysis of human keratinocyte prostaglandin synthesis: endogenous TNF $\alpha$ is involved in ultraviolet radiation-induced PGE $_{2}$ synthesis. Arch Dermatol. Res. 284:40. (Abstr.).

35. Schwarz, T., and T. A. Luger. Effect of UV irradiation on epidermal cell cytokine production. J. Photochem. Photobiol. 4:1-16.

36. Koch, F., C. Heufler, D. Schneeweiss, E. Kämpgen, and G. Schuler. 1989. Tumor necrosis factor $\alpha$ maintains the viability of murine epidermal Langerhans cells in culture but in contrast to GM-CSF without inducing their functional maturation. J. Exp. Med. 171:159-164.

37. Yoshikawa, T., and J. W. Streilein. 1990. Genetic basis of the effects of ultraviolet light $\mathrm{B}$ on cutaneous immunity. Evidence that polymorphism at the TNF $\alpha$ and LPS loci governs susceptibility. Immunogenetics. 32:398-405.

38. Vermeer, M., and J. W. Streilein. 1990. Ultraviolet B light-induced alterations in epidermal Langerhans cells are mediated in part by tumor necrosis factor-alpha. Photodermatol. Photoimmunol. \& Photomed. 7:258-265.

39. Piguet, P. F., G. E. Grau, C. Hauser, and P. Vassalli. 1991. Tumor necrosis factor is a critical mediator in hapten-induced irritant and contact hypersensitivity reactions. J. Exp. Med. 173:673-679.

40. Boehm, K., and C. A. Elmets. 1992. Human epidermal cytokine transcript level changes in situ following urushiol application. J. Invest. Dermatol. 98:571. (Abstr.) 